\title{
COVID-19 Related to Liver Impairment and Its Impact on Chronic Liver Disease
}

\author{
Andri Sanityoso Sulaiman, Juferdy Kurniawan, Chyntia OM Jasirwan, \\ Saut HH Nababan, Kemal F Calista, Cosmas Rinaldi A Lesmana, Irsan Hasan, \\ Rino Alvani Gani, Baiq Kirana DN Mandasari \\ Division of Hepatobiliary, Department of Internal Medicine, Faculty of Medicine, \\ Universitas Indonesia/Dr. Cipto Mangunkusumo General National Hospital, Jakarta
}

\section{Corresponding author:}

Andri Sanityoso Sulaiman. Division of Hepatobiliary, Department of Internal Medicine, Dr. Cipto Mangunkusumo General National Hospital. Jl. Diponegoro No. 71 Jakarta Indonesia. Phone: +62-21-31900924; facsimile:+62-21-3918842.Email: andri_sani@yahoo.com

\begin{abstract}
By late December 2019, a novel beta-coronavirus, named as COVID-19 (2019-nCoV), was discovered in Wuhan, Hubei Province, China which epidemiologically linked to a Huanan seafood market in Wuhan. Coronavirus Disease 2019 or COVID-19 cases are growing rapidly from Wuhan to many countries, finding the health care system unprepared to face this threat. No effective drugs are clinically approved to manage the disease and strategies to protect the most vulnerable from developing severe illness and infection is still unclear. Information on how COVID-19 virus infection may affects many organs, especially the liver and the relevance of pre-existing liver disease in patients as a risk factor for the infection or disease severity are still scarce and inconclusive. Besides, the recommendation and consideration in liver transplant patients, hepatocellular carcinoma, or patient on immunosuppressive therapy still need further analysis Therefore, the information on the mechanism and treatment of COVID-19 related liver injury in patients with or without pre-existing liver disease should be considered.
\end{abstract}

Keywords: COVID-19, coronavirus, liver impairment, chronic liver disease, infection

\section{ABSTRAK}

Pada akhir desember 2019, beta-coronavirus baru, disebut dengan COVID-19 (2019-nCoV) ditemukan di Wuhan, Provinsi Hubei, China yang secara epidemiologi berkaitan erat dengan pasar hewan di Wuhan. Kasus infeksi Coronavirus Disease 2019 atau COVID-19 masih meningkat secara masif dari Wuhan hingga ke negara-negara lainnya, menandakan adanya ketidaksiapan lembaga kesehatan dalam menghadapi pandemic ini. Hingga saat ini, belum ditemukan rekomendasi tatalaksana yang efektif untuk infeksi COVID-19 dan belum ada strategi yang jelas bagi orang-orang yang memiliki kerentanan untuk menderita infeksi yang berat. Informasi bagaimana infeksi virus COVID-19 dapat mempengaruhi organ lain, khususnya organ hati, dan relevansi penyakit hati kronik sebagai faktor risiko keparahan infeksi COVID-19 masih terbatas dan inkonklusif. Selain itu, rekomendasi manajemen pasien dengan peyakit hati seperti pasien transplantasi hati, karsinoma sel hati, atau pasien dalam terapi imunosupresan masih membutuhkan analisis lebih jauh. Oleh karena itu, mekanisme dan tatalaksana infeksi COVID-19 terhadap gangguan fungsi hati pada pasien dengan atau tanpa penyakit hati kronik harus dipertimbangkan.

Kata kunci: COVID-19, coronavirus, gangguan hati, penyakit hati kronik, infeksi 


\section{INTRODUCTION}

By late December 2019, a novel beta-coronavirus, named as COVID-19 (2019-nCoV), was discovered and was isolated from the airway epithelial cell of patient with unknown pneumonia in Wuhan, Hubei Province, China. Within four months, COVID-19 cases were growing rapidly from Wuhan to many countries, globally. ${ }^{1,2,3}$ As of July $4^{\text {th }}, 2020$, the total of confirmed case are 10,902,637 cases including 522,466 death worldwide, finding the health care system unprepared to face this threat. ${ }^{4}$ In Indonesia, there are 62.142 total confirmed case and 3.089 death per $4^{\text {th }}$ July $2020 . .^{5}$

Coronaviruses belong to a large family of singlestranded RNA viruses. Coronaviruses are classified alpha-coronavirus, beta-coronavirus, gammacoronavirus, and delta corona virus. ${ }^{1,2}$ As zoonotic viruses, wild animals and bats as the natural reservoir host and have a crucial role in transmitting the virus to humans. ${ }^{1,2}$ SARS-CoV-2 has three dimensions structure of spike glycoprotein receptor-binding domain which binds to angiotensin-converting enzyme 2 (ACE2) receptor as it infects human cells. ${ }^{1,2,3}$ The main route of transmission for SARS-CoV-2 is the respiratory droplet, however, it can also be transmitted through aerial droplets, as well as direct and indirect contact by touching the surface of daily objects. ${ }^{1,2,6}$ Recent studies showed demonstrated detection of RNA and parts of SARS-CoV-2 in feces; indicating the ability of the virus to replicate in digestive tract, which can be manifested as gastrointestinal symptoms with possible oral-fecal transmission. ${ }^{7}$

Clinical manifestations of COVID-19 are highly variable; ranging from asymptomatic, mild, moderate, and severe. Furthermore, in elderly or immunocompromised patients, the clinical manifestations can be atypical. ${ }^{1,2,3}$ Information on how SARS-CoV-2 affects many organs, especially hepatobiliary system, and the relevance of pre-existing liver disease in patients as a risk factor for the infection or progression of disease severity are still scarce and inconclusive. ${ }^{8,9}$ Not to mention that recommendations and considerations in liver transplant patients, hepatocellular carcinoma, or in patients with immunosuppressive therapy still need further analysis. ${ }^{10}$ Therefore, the information on the mechanism and treatment of COVID-19 related liver injury in patients with or without pre-existing liver disease should be considered. Also, since the number of COVID-19 cases keeps increasing and no potential drugs have been proven clinically, it is essential to develop strategies to protect the most vulnerable from developing severe illness and infection.

\section{HOW COVID-19 AFFECT THE LIVER}

The impact of COVID-19 virus infection on the liver is still unclear. Several studies have shown that COVID-19 virus infection causes abnormality in liver function proven by elevation of serum liver biochemistries such as alanine aminotransferase (ALT), aspartate aminotransferase (AST), and total bilirubin. The incidence of elevated ALT and AST are ranged from $2.5 \%-50 \%$ to $2.5 \%-61.1 \%$, respectively. ${ }^{10-13}$ Low of albumin level is also a marker of severe infection and poor prognosis. ${ }^{14,15}$ Several studies also evaluated alkaline phosphatase (ALP) and gamma glutamyl-transpeptidase (GGT) for the assessment of liver function. ${ }^{10-13}$ This is possible because of ubiquitous distribution of the main viral entry receptor, angiotensin converting enzyme 2 (ACE2), causing systemic systemic infection and alteration in the immune system. ${ }^{10-15}$ The COVID-19 related liver injury is defined as any liver damage occurring during disease progression and treatment of COVID-19 in patients with or without pre-existing liver disease. ${ }^{16-18}$ There are several possible pathogenesis and pathophysiology of COVID-19 related liver injury: (1) Severe and systemic inflammation responses following COVID-19 virus infection are due to immune-mediated damage. This hypothesis is supported by studies that found that the inflammation biomarkers including $\mathrm{C}$ reactive protein (CRP), serum ferritin, LDH, D-dimer, IL-6, and IL-2 were elevated significantly in severe COVID-19 patients. Following autopsy studies, liver changes include dark red hepatomegaly, hepatocyte degeneration with focal lobular necrosis, and infiltration by neutrophils, lymphocytes, and monocytes in the portal spaces, and sinusoidal congestion with micro thrombosis. Despite these findings, no lesions of the bile ducts or liver failure can be specifically attributed to COVID-19 virus infection ${ }^{19,20,21}$; (2) Direct cytotoxicity is the result of active viral infection and replication in hepatic cells. This hypothesis is supported by several studies that found that the COVID-19 virus receptor, the ACE2, is expressed abundantly in the liver and in particular on biliary epithelial cells (59.7\% vs. $2.6 \%$ in hepatocyte), suggesting cholangiocyte dysfunction may contribute to liver injury. The liver pathology of COVID-19 patients showed moderate microvascular steatosis, mild lobular and portal activity, and a significant increase in mitotic cells and ballooned hepatocytes, indicating the apoptosis of the liver cell and could become evidence of direct liver infection. Additionally, although the viral load was relatively low, the virus was detected 
in liver tissue. Tan et al have also demonstrated that COVID-19 virus specific protein 7a induces apoptosis via a caspase-dependent pathway in cell lines of different organs, including the liver, further confirming the possibility that COVID-19 virus directly affects liver tissue. However, no evidence that the late-onset symptoms are associated with greater liver function damage. Further evaluations are needed. ${ }^{8,22,23} ;(3)$ Anoxia as the result of respiratory failure. Hypoxic hepatitis is found in severe cases of anoxia COVID-19 patient. ${ }^{13,16,24}$; (4) Drug-induced liver injury (DILI) due to some drugs, which include antiviral, antibiotic, chloroquine, tocilizumab, and traditional medicine. $\mathrm{Xu}$ et al suggested some potentially hepatotoxic drugs in treating COVID-19, especially hydroxychloroquine, azithromycin, and some antiviruses (lopinavir/ ritonavir). ${ }^{16,24,25}$; (5) Reactivation of pre-existing liver disease. Patients with pre-existing chronic liver disease, may be more susceptible to liver damage from SARS-CoV-2 infection. Biologic agents such as tocilizumab and baricitinib might also cause hepatitis $\mathrm{B}$ virus (HBV) reactivation and thus lead to liver function deterioration. On the other hand, it is still unknown whether SARS-CoV-2 infection exacerbates cholestasis in those with underlying cholestatic liver disease. ${ }^{16,26}$

Study by Vespa et al confirmed that prevalence COVID-19 patient with elevated ASL and ALT values were $18.5 \%$ and $26.7 \%$ respectively. An increase of GGT $>55 \mathrm{U} / \mathrm{L}$ was seen in $36.2 \%$, ALP $>150 \mathrm{U} / \mathrm{L}$ in $9.6 \%$, and total bilirubin $>1,2 \mathrm{mg} / \mathrm{dl}$ in $10.6 \%$. The result of the study also showed that the clinical value of ALP is associated with poor prognosis. ${ }^{27}$ Wang et al in their study found that $41 \%$ of COVID-19 patient had elevated aminotransferase. The enzyme abnormality was associated with disease severity, along with other series of laboratory tests including higher A-aDO2, higher GGT, lower albumin, decreased CD4+ T cells, and B lymphocytes. ${ }^{28}$

\section{CHRONIC LIVER DISEASE AND COVID-19}

Chronic liver disease (CLD) with or without cirrhosis are one of the conditions related to decreased immune function caused by dysregulation or abnormal immune system. ${ }^{29,30}$ This condition could lead to an increased risk of severe acute respiratory infections and complications during COVID-19 virus infection. ${ }^{26}$ The prevalence of COVID-19 patients with pre-existing liver disease ranges from $2 \%-11 \% .{ }^{11}$ However, studies on how the effect of COVID-19 virus infection among patient with chronic liver disease are still inconclusive.

Andre et al in their study on the mortality rate of COVID-19 virus infection in patients with preexisting chronic liver disease and cirrhosis found that patients with chronic liver disease and cirrhosis had clinical factors associated with poor outcomes from COVID-19 virus infection. Among 152 patients with chronic liver disease and COVID-19 virus infection, $68 \%$ (103 patients) of them were cirrhosis. The most common etiology of the pre-existing liver disease was non-alcoholic fatty liver disease $(22.4 \%)$, followed by alcohol liver disease $(19,7 \%)$, hepatitis B $(11.8 \%)$, hepatitis C (10.5\%), and others/combination (35.6\%). The median length of hospital stay until discharge or death was 10 days in cirrhotic patients. The mortality rate among cirrhosis patients remains high (39.8\%). The reported causes of death in cirrhosis patients were COVID-19 lung disease in $78 \%$ of patients, cardiacrelated in $4.3 \%$, and only $12.2 \%$ of death was related to liver disease. ${ }^{31}$ This study showed that the risk factors for poor prognosis and severe outcomes in the general population were advanced age, obesity, renal impairment, heart disease, and diabetes mellitus. ${ }^{31} \mathrm{In}$ cirrhotic patients, baseline Child-Turcotte-Pugh (CTP) class and Model for End-stage Liver Disease (MELD) scores were strongly correlated to mortality risk. ${ }^{31}$ The result of this study showed that death occurred in $12.2 \%$ of chronic liver disease (CLD) without cirrhosis, $23.9 \%$ of which were CTP-A, $43.3 \%$ were CTP-B, and $63.0 \%$ were CTP-C. CTP-B and CTP-C cirrhosis remained a significant predictor of mortality. ${ }^{31}$ The presence of hepatic decompensation (worsening ascites, spontaneous bacterial peritonitis, hepatic encephalopathy, and variceal hemorrhage) during COVID-19 virus infection was also strongly correlated with a high risk of death, with $63.2 \%$ of those with new decompensation died compared to $26.2 \%$ of those without new decompensation. About $24.3 \%$ of patients with new decompensation had no respiratory symptoms. ${ }^{31}$ These results are quite similar to Major et al study, which found that 562 COVID-19 patients with chronic liver disease ( $53 \%$ with cirrhosis) had a high rate for hospitalization and Intensive Care Unit admission. The CTP score was correlated significantly with increased the rate of death. Patients with liver cirrhosis may develop acute-on-chronic liver failure caused by an overwhelming inflammatory response and have a higher risk of secondary bacterial infection. ${ }^{32}$

Dong Ji et al who analyzed non-alcoholic fatty liver disease (NAFLD) in patients with COVID-19 concluded that patients with NAFLD with high body 
mass index (BMI) had a higher risk of progression to severe COVID-19 virus infection with longer viral shedding time. ${ }^{33} \mathrm{~A}$ large population of NAFLD could be at risk of severe COVID-19 due to an increased prevalence of NAFLD and the presence of concomitant extra-hepatic manifestation of metabolic syndrome. ${ }^{33}$ The underlying pathogenesis and pathophysiology are still unclear but could be related to impaired innate immunity to the virus and impaired hepatic function. ${ }^{33,34}$ Patients with NAFLD have impaired hepatic macrophages function which is indicated by an increased ratio of inflammation-promoting M1 macrophages to inflammation-suppressing M2 macrophages. This condition could lead to the disease progression of COVID-19. ${ }^{33,34,35}$ As NAFLD patients have often shown elevated cytokine levels, these patients may also be vulnerable to increased cytokine production associated with COVID-19 virus infection. ${ }^{33,34,35}$ Another study on 202 COVID-19 patients revealed that 76 patients with NAFLD had a higher risk of severe disease $(44.7 \%$ vs. $6.6 \%, \mathrm{p}<$ $0.0001)$, higher abnormal liver function tests $(70 \%$ vs $11.1 \%, \mathrm{p}<0.0001)$ and longer viral shedding time $(17.5 \pm 5.2$ days vs $12.1 \pm 4.4$ days, $p<0.0001)$ when compared to non-NAFLD patients. ${ }^{33}$

The COVID-19 virus infection has not been shown to cause severe disease in patients with immunosuppressive therapy, especially liver transplant recipients or autoimmune hepatitis patients. ${ }^{36}$ However, still, the clinician should manage a particular concern about immunocompromised patients. Bergamo et $\mathrm{al}$, in their study, suggested that immunosuppressed patients were not at increased risk for COVID-19 virus infection. ${ }^{26}$ Surprisingly, when an infection of an immunocompromised host occurs, it may be protected by a weaker immune response against the infectious agent. Based on available data, Ana Lieo et al suggested that immunosuppressed patients, especially those with autoimmune hepatitis (AIH), cirrhosis receiving immunosuppressive therapy, or liver transplant patients did not need to reduce or withdraw their immunosuppressive drugs to avoid a flare which would then require a higher dose of steroid and thus potentially increased the risk of infection. ${ }^{37}$ The EASL-ESCMID recommends that reduction should only be considered in case of severe COVID-19 under special circumstances (drug-induced lymphopenia or bacterial/fungal superinfection. Marjot Tom et al in his study found that patients with AIH had a modest reduction in the rate of hospitalization $(75 \%)$ but with equivalent rates of death compared with CLD from other etiologies, despite the use of immunosuppressive agents. ${ }^{32}$ However, the number of cases was small, thus a further larger study to establish this conclusion.

The post-transplant consideration is quite complex because of the higher risk of severe infection when patients receive excessive immunosuppression. Bin et al described a case of a 50-year-old male post-liver transplantation who was infected by SARS-CoV-2. The patient recovered from severe COVID-19 pneumonia after a temporary withdrawal of immunosuppressive agent and administration of a systemic low-dose corticosteroid.$^{38}$ Huang and colleagues reported a case of COVID19 in a patient who had transplantation three years previously for HCC with a poor outcome despite multiple aggressive therapeutic measures. ${ }^{39}$ The disease progressed rapidly from mild to critical illness because of multiple nosocomial infections and multiple organ failure. ${ }^{38,39}$ Garido et al suggested that post-transplant metabolic complications might outweigh immunosuppression as a risk factor for the development of severe COVID-19. ${ }^{36}$ In this regard, the EASL-ESCMID suggests a reduction of immunosuppressive therapy in post-transplant patients with severe COVID-19 only under special circumstances (medication-induced lymphopenia, bacterial/fungal superinfection. ${ }^{40}$ Huang et al suggested that lower $\mathrm{T}$ cell count in the post-transplant patient may be a surrogate for poor outcomes. ${ }^{39}$ Lavarone et al in their study showed that among fifty cirrhotic patients with confirmed COVID-19 infection, acute on chronic liver failure and de novo acute liver injury occurred in $14(28 \%)$ patients and 10 patients, respectively. COVID-19 virus infection is associated with liver function deterioration and elevated mortality in cirrhotic patients. ${ }^{44}$ Wong et al in study about management of patients with liver derangement during the COVID-19 pandemic suggested that systemic high-dose corticosteroid and tocilizumab which have been advocated for treating COVID-19 infection might cause $\mathrm{HBC}$ reactivation, hepatitis flare, and acute liver failure among patient with chronic $\mathrm{HBV}$ infection who confirmed positive COVID-19 virus infection. ${ }^{45}$

Several studies reported that patients with cancer or malignancy have a higher risk of COVID-19 virus infection with poorer outcomes compared to the general population..$^{50}$ It is associated with systemic immunosuppressive state and treatment, such as chemotherapy or surgery. ${ }^{50}$ Zhang et al in their study of 28 cancer patients with severe COVID-19 virus infection, two of them with hepatocellular carcinoma. 
Half of the patients had severe events with mortality rate was $28.6 \%{ }^{51}$ Anti-cancer therapy which was given within 14 days increased the risk of developing severe events significantly, including patients with $\mathrm{HCC}$ who showed deteriorating conditions and poor outcomes. Thus, intensive surveillance and early admission for cancer patients with COVID-19 virus co-infection are imperative. ${ }^{51-52}$

\section{CONCLUSION}

COVID-19 infection has spread globally and to date, the case and the death rate are still increasing. Clinical manifestations of COVID-19 virus infection are quite wide from asymptomatic, mild, moderate, and severe and can be atypical especially in elderly or immunocompromised patients. However, COVID-19 related to liver impairment and its impact on chronic liver disease is still unclear. Several studies have shown COVID-19 virus infection causes abnormality in liver function proven by elevated of serum liver biochemistries associated to progressive disease and poor outcome. Some possibilities about the pathogenesis and pathophysiology of COVID-19 associated liver injury are included severe and systemic inflammation responses following COVID-19 virus infection resulting immune mediated damage, direct cytotoxicity, hypoxia, drug induce liver injury (DILI), and reactivation of pre-existing liver disease. However, the prevalence of chronic liver disease with COVID-19 infection co infection is relatively low. This study found that pre-existing liver disease appears to have low impact on COVID-19 outcomes. Nevertheless, some studies suggested that individual with NAFLD, high score of CTP, poor liver function before infection, and experience acute on chronic and acute liver failure have poorer prognosis.

\section{REFERENCES}

1. Susilo A, Rumende GM, Pitoyo Ceva W, Santoso WD, Yulianti M, Herikurniawan, et al. Coronavirus disease 2019: review of current literatures. Jurnal Penyakit Dalam Indonesia 2020:7;45-77.

2. Wu Di, Wu Tiantian, Liu Qun, Yang Zhicong. The SARSCoV-2 outbreak: what we know. International Journal of Infectious Disease Elsevier 2020:94;44-8.

3. Zhua N, Zhang D, Wang W, Li X, Yang B, Song J, et al. A novel coronavirus from patients with pneumonia in China, 2019. N Eng J Med 2020;382:727-33

4. World Health Organization. WHO coronavirus disease 19 (COVID-19) dashboard [serial online] [cited 2020 July 4]. Available from: https://covid19. who.int/?gclid=Cj0KCQjw0YD4BRD2ARIsAHwmKVm0XVJO9JdFIJU8GGsqVd28r ymaJjMUTEQ1P6pvESU8Vs7FdqxUawkaAsMgEALw_wcB
5. Gugus Tugas Percepatan Penanganan COVID-19. Infografis COVID-19 (4 Juli 2020) [serial online] [cited 2020 July 4]. Available from: https://covid19.go.id/p/berita/infografisCOVID-19-04-juli-2020

6. Li Q, Guan X, Wu P, Wang X, Zhou L, Tong Y, et al. Early transmission dynamic in Wuhan, China, of novel coronavirusinfected pneumonia. N Engl J Med 2020; 382: 1199-207.

7. Pan L, Mu M, Yang P, Sun Y, Wang R, Yan J, et al. Clinical Characteristics of COVID-19 Patients With Digestive Symptoms in Hubei, China: A Descriptive, Cross-Sectional, Multicenter Study. Am J Gastroenterol 2020;115:766-73.

8. Chai X, Hu L, Zhang Y, Han W, Lu Z, Ke A, et al. Specific ACE2 expression in cholangiocytes may cause liver damage after 2019-nCoV infection. The Preprint Server for Biology 2020;2020:1

9. Smet VD, Verhulst S, Grunsven LA. Single cell RNA sequencing analysis did not predict hepatocyte infection by SARS-CoV-2. J Hepatol 2020;73:993-5.

10. Ridruejo E, Soza A. The liver in times of COVID-19: What hepatologists should know. Ann Hepatol 2020;19:353-358.

11. Zhang C, Shi L, Wang FS. Liver injury in COVID-19: management and challenges. Lancet Gastroenterol 2020;5:42830 .

12. Guan WJ, Ni ZY, Hu Y, Liang WH, Ou CQ, He JX, et al. Clinical characteristic of coronavirus disease 2019 in China. N Eng J Med 2020;382:1708-20.

13. Cai Q, Huang D, Yu Hong, Zu Z, Xia Z, Su Y, et al. COVID-19: abnormal liver function test. J Hepatol 2020;73:566-74.

14. Fu Y, Han P, Zhu R, Bai T, Yi J, Zhao X, et al. Risk factors for viral RNA shedding in COVID-19 patients. Eur Resp J 2020;56:2001190.

15. Ramadori Giuliano. Hypoalbuminemia: an underestimated, viral characteristic of hospitalized COVID-19 positice patients?. Hepatoma Res 2020;6:28

16. Sun J, Aghemo A, Forner A, Valenti L. COVID-19 and liver disease. Liver International 2020;40:1278.

17. Huang C, Wang Y, Li X, Ren L, Zhao J, Hu Y, et al. Clinical features of patients infected with 2019 novel coronavirus in Wuhan. China. Lancet 2020;395:497-506.

18. Wang D, Hu B, Hu C, Zhu F, Liu X, Zhang J, et al. Clinical characteristics of 138 hospitalized patients with 2019 novel coronavirus-infected pneumonia in Wuhan, China. JAMA 2020;323:1061.

19. Liu J, Li S, Liu J, Liang B, Wang X, Wang H, et al. Longitudinal characteristics of lymphocyte responses and cytokine profiles in the peripheral blood of SARSCoV-2 infected patients. EBioMedicine 2020;55:102763.

20. Guan WJ, Ni ZY, Hu Y, Liang WH, Ou CQ, He JX, et al.; China Medical Treatment Expert Group for COVID-19. Clinical characteristics of coronavirus disease 2019 in China. N Engl J Med 2020;382:1708-20.

21. Peixe P, Calinas F, Tato Marinho R: Hepatology in the COVID Era: Another C Virus, again Challenging the Liver. GE Port J Gastroenterol 2020;27:230-6.

22. Chau TN, Lee KC, Yao H, Tsang TY, Chow TC, Yeung YC, et al. SARS-associated viral hepatitis caused by a novel coronavirus: report of three cases. Hepatology 2004;39:30210.

23. Tan YJ, Fielding BC, Goh PY, Shen S, Tan TH, Lim SG, et al. Overexpression of $7 \mathrm{a}$, a protein specifically encoded by the severe acute respiratory syndrome coronavirus, induces apoptosis via a caspase-dependent pathway. J Virol 2004;78:14043-7. 
24. Xu L, Liu J, Lu M, Yang D, Zheng X. Liver injury during highly pathogenic human coronavirus infections. Liver Int 2020;40:998-1004.

25. Boeckmans J, Rodrigues RM, Demuyser T, Piérard D, Vanhaecke T, Rogiers V. COVID-19 and drug-induced liver injury: a problem of plenty or a petty point? Arch Toxicol 2020;94:1367-9.

26. D'Antiga L. Coronaviruses and immunosuppressed patients. The facts during the third epidemic. Liver Transpl 2020;26:832-4.

27. Vespa E, Pugliese N, Piovani D, Capogreco A, Danese S, Aghemoe A. Liver tests abnormalities in COVID-19: trick or treat? J Hepatol 2020;73:1275-6.

28. Wang Y, Liu S, Liu H, Li W, Lin F, Jiang L, et al. SARS-CoV-2 infection of the liver directly contributes to hepatic impairment in patients with COVID-19. J Hepatol 2020;73:807-16.

29. Su TH, Kao JH. The clinical manifestations and management of COVID-19-related liver injury. J Formos Med Assoc 2020;119:1016-8.

30. Mantovani, A, Beatrice, G, Dalbeni, A. Coronavirus disease 2019 and prevalence of chronic liver disease: A metaanalysis. Liver Int 2020;40:1316-20.

31. Moon AM, Webb GJ, Aloman C, Armstrong MJ, Cargill T, Dhanasekaran R, et al. High Mortality Rates for SARS-CoV-2 Infection in Patients with Pre-existing Chronic Liver Disease and Cirrhosis: Preliminary Results from an International Registry. J Hepatol 2020;73:705-8.

32. Marjot Tom. COVID-19 in patients with autoimmune liver disease and cirrhosis: data from the COVID-Hep and SECURE-cirrhosis registries. [serial online] [cited 2020 November 01]. Available from: https://ec.europa.eu/health/ sites/health/files/ern/docs/ev_20200604_co04_en.pdf

33. Ji D, Qin E, Xu J, Zhang D, Cheng G, Wang Y, et al. Nonalcoholic fatty liver diseases in patients with COVID-19: A retrospective study [published online ahead of print, 2020 Apr 8]. J Hepatol 2020;73:451-3.

34. Prins GH, Olinga P. Potential implications of COVID-19 in non-alcoholic fatty liver disease. Liver Int 2020;x:10.1111/ liv. 14484.

35. Philips CA, Ahamed R, Augustine P. SARS-CoV-2 related liver impairment - perception may not be the reality [published online ahead of print, 2020 May 23]. J Hepatol 2020;x:S01688278(20)30344-5.

36. Garrido I, Liberal R, Macedo G. Review article: COVID-19 and liver disease-what we know on 1st May 2020. Aliment Pharmacol Ther 2020;52:267-75.

37. Lleo A, Invernizzi P, Lohse AW, Aghemo A, Carbone M. Highlights for management of patients with autoimmune liver disease during COVID-19 pandemia. J Hepatol 2020;73:4535.

38. Bin L, Yangzhong W, Yuanyuan Z, Huibo S, Fanjun Z, Zhishui C. Successful treatment of severe COVID-19 pneumonia in a liver transplant recipient. Am J Transplant 2020;20:1891-5.

39. Huang JF, Zheng KI, George J, Gao HN, Wei RN, Yan $\mathrm{HD}$, et al. Fatal outcome in a liver transplant recipient with COVID-19. Am J Transplant 2020;20:1907-10.

40. Boettler T, Newsome PN, Mondelli MU, Maticic M, Cordero E, Cornberg M, et al. Care of patients with liver disease during the COVID-19 pandemic: EASL-ESCMID position paper, JHEP Reports 2020;2:100113.

41. Liang W, Guan W, Chen R, Wang W, Li J, Xu K, et al. Cancer patients in SARSCoV-2 infection: a nationwide analysis in China. Lancet Oncol 2020;21:335-7.
42. Zhang L, Zhu F, Xie L, Wang C, Wang J, Chen R, et al. Clinical characteristics of COVID19-infected cancer patients: a retrospective case study in three hospitals within Wuhan, China. Ann Oncol 2020;31:894-901.

43. European Association for the Study of the Liver. EASL Clinical Practice Guidelines: management of hepatocellular carcinoma. J Hepatol 2018;69:182-236.

44. Lavarone M, Ambrosio R, Soria A, et al. High rate of 30-day mortality in patients with cirrhosis and COVID-19. J Hepatol 2020;73:1063-71.

45. Wong GL, Wong VW, Thompson A, Jia J, Hou J, Lesmana CR, et al. Management of patients with liver derangement during the COVID_19 pandemic: an asia pacific position statement. Lancet Gastroenterol Hepatology 2020;5:776-87. 